MIROSLAW MOROZ

\title{
Innovations in e-business \\ - new ways of delivery of food products over \\ the Internet \\ in the opinion \\ of potential customers
}

Ph.D. Miroslaw Moroz Wroclaw University of Economics Department of Economics and Organization of Enterprises

\section{Introduction}

E-commerce based on selling products and services via the Internet develops very fast. The increase is connected with the transaction volume, as well as with the percentage of the Internet users using e-commerce. Great demands are connected with logistic aspects of e-business functioning - time and expense of delivery. E-shops struggle with the so called "the last mile issue". The above term refers to efficient and effective service of the last link in the logistics chain which is the customer. Consumer's service is bound to geographical dispersion of clients. Mail delivery to a given client's address (e-shop being within the range of the deal) appears to be time-and-cost challenge.

The last mile issue is significant for these segments of e-commerce which are based on fast moving consumer goods. In particular, it refers to food products sale via the Internet. This segment has been recently undergoing dynamic development.

This article's objective is the two-fold one. An analysis of an innovative solution to the last mile issue comes as first. It concerns Freshbox 
project introduced by Frisco.pl company. The second objective is to evaluate the usefulness Freshbox project made by three groups of potential customers: current students, students that study and work (extramural studies), and office workers of one of the Polish banks comes as second.

The paper employs semi-structured interviews with respondents. The research has been conducted among three groups of potential clients: prospect and current office workers. A qualitative approach is justified in the case of new problem. Qualitative analyses are appropriate for studying phenomena that are not well known (Edmondson, McManus 2007, p. 1155). The Freshbox project is the new solution of the Last Mile Issue in the context of sale of food products through the Internet.

\section{The specificity of online grocery stores}

E-commerce created new possibilities of purchasing products and services. Through the transaction-based using of the Internet, clients have the access to a wider assortment, they can buy things in a convenient way, use the alternative ways of doing transactions (auctions), as well as they can economize on prices in many cases. Transactional possibilities of virtual space helped e-shops come into being. Retail sale via the Internet indicates a dynamic increase in consequence; for instance, the increase of financial e-transactions in Great Britain reached $720 \%$ as for the 1999-2005 time span (Weltevreden 2008, p. 638).

As far as the Polish e-commerce is concerned, the increase is also beyond doubt. According to the "Internet 2k10" report, the amount of total Polish retail e-commerce increased $12,7 \%$ in comparison to previous year. Participation of e-sale within retail sale in Poland was circling around 3\% towards the end of 2010, whereas analogical rate was at the level of 10\% in Great Britain (Anonym 2010).

Food sale via the Internet is one of the most dynamic e-commerce segments that notes a dynamic increase. Food products, due to their specificity, are very demanding items in an online sale. A human-being experiences such type of products through senses of smell and taste, whereas the message in the Internet is based on senses of sight and hearing. Moreover, food products are susceptible to the passing of time (freshness issue) and transport conditions (tainted, rotten outdated, defrosted fruits). Therefore, the development of sale of food products in the Internet is slow due to positive Internet users' experience referring to other product categories. Table 1 shows advantages and disadvantages of buying food products via the Internet from the consumer's perspective. 


\section{Table 1. Advantages and disadvantages of food purchasing} on the Internet - a customer perspective

\begin{tabular}{|c|c|c|}
\hline & Advantages & Disadvantages \\
\hline $\begin{array}{l}\text { Specific } \\
\text { features for } \\
\text { online grocery }\end{array}$ & $\begin{array}{l}\text { Door-to door transport of heavy } \\
\text { products } \\
\text { Check list of basics saved on system } \\
\text { of online grocery } \\
\text { Great selection of available products } \\
\text { Range of information about products } \\
\text { Purchase convenience (no need to } \\
\text { prepare oneself to go out the house, } \\
\text { to reach the shop, to park the car, } \\
\text { to search the given product among } \\
\text { shelves, to stand in the crowded } \\
\text { space and to queue) }\end{array}$ & $\begin{array}{l}\text { Initial set-up of client account is time } \\
\text { consuming } \\
\text { Relatively high price of food products in } \\
\text { Polish internet grocery } \\
\text { No physical place to complain } \\
\text { Shopper can't get end of aisle bargains } \\
\text { Time lag between order and delivery } \\
\text { The risk of partial delivery of ordered } \\
\text { products } \\
\text { The risk of debatable quality of ordered } \\
\text { products (old, defrosted, squeezed) } \\
\text { The lack of the possibility to taste }\end{array}$ \\
\hline $\begin{array}{l}\text { Features } \\
\text { concerning all } \\
\text { e-commerce } \\
\text { categories }\end{array}$ & $\begin{array}{l}\text { E-shop open } 24 \mathrm{~h} / 7 \text { days } \\
\text { Shoppers don't have to deal with } \\
\text { pushy salesman } \\
\text { Ease of comparing prices in the } \\
\text { Internet } \\
\text { The possibility of ordering directly } \\
\text { from the house }\end{array}$ & $\begin{array}{l}\text { The lack of trust to online purchase } \\
\text { The lack of trust to online payment } \\
\text { The necessity to spare time to take the } \\
\text { delivery } \\
\text { Confusing homepage design/layout } \\
\text { (Web-usability) } \\
\text { Slow connection or website }\end{array}$ \\
\hline
\end{tabular}

Source: own elaboration based on Ramus, Nielsen 2005; Robinson et al. 2007

Accepting the consumer's perspective is crucial for further expansion of this segment of e-commerce (Huang, Oppewal 2006, p. 337). Advantages, as well as disadvantages pointed out in the table form the list of factors the online grocery segment has to focus on. Features collected in the table are differentiated due to the meaning for potential client, due to the fact that food products enjoy their own specificity - they are done on regular basis with significant frequency, they are diversified, they comprise, at least, several assortment groups and they are very susceptible to time span issues (expiry date, incentive-based willingness to a given product in a particular moment) (Milkman et al. 2010, p. 21).

As far as the client's perspective is concerned, convenience and saving the time are the most important advantages while buying food products via the Internet. Convenience is understood as the lack of interrelated elements: searching for a given product among the shelves, crowded spaces, queuing, bringing the products home. Especially the last feature is being strongly highlighted when it comes to buying heavy products (mineral water, flour, sugar). Saving the time is an important aspect, due to shifting the responsibility of the above 
mentioned activities onto the shop. According to the research, the Pole spends 3 hours on shopping weekly - that is 160 hrs yearly (Laskowska 2010). The choice of products and standing in queues account for $43 \%$ of time associated with shopping, whereas $57 \%$ of mentioned above time is devoted to getting to the shop and parking. The above data make possible saving of time, due to using online grocery, more visible.

However, there are also some disadvantages related to food products being bought via the Internet.

The key issue is narrowed to the delivery one. Most reservations refer to logistics. Delays in delivery are the very first perceptible discomfort. The order, as in standard mode of delivery, will appear on client's table within few hours or the next day. Cuisine ideas may change dramatically during this time. Moreover, chosen and planned deliveries may sometimes be disrupted (trafficjams, demurrages, a sudden change of itinerary). Therefore, a huge load of criticism is dished out by Internauts; their complaints stem from the fact that they did not order via the Internet to waste their time waiting for the courier. The condition of goods, connected with logistics, after they reach their destination is another issue. This stage carries the risk of product damages or defrosting products requiring low temperatures. Incomplete deliveries (the lack of some previously ordered products) remain in the same problematic theme, as it means the lack of some indispensable ingredients constituting a given dish.

\section{Characteristics of the project Freshbox}

Logistic conditions and limitations existing in online groceries were highlighted in the previous part of the article. The implementation of the so called intermediate solutions is one of possible answers. They are based on the lack of necessity of delivering the order directly to the client's door. Sellers can create physical pick-up points instead, from where a client takes back the order at his or her own convenience. One can overcome high costs at the final stage of delivery and diminish the significance of the last mile issue this way.

One can differentiate two types of intermediate solutions reducing the significance of the last mile issue (Esser 2008):

1. Personal solutions:

- collection/delivery point (Pick-up points) - such as shops, news-stands.

2. Automatic solutions:

- package boxes - for the limited circles of people,

- locker facilities - in places open for general use. 
Generally speaking, the idea behind all the above solutions is based on creating a collective spot in which deliveries can be stored for clients of a given area. Other words, logistic operator does not deliver mail to every single client but mail is delivered collectively - to a given locker facility, for instance. It makes deliveries easy and lowers the logistic costs as well. The client enjoys the possibility of taking his or her mail back in non-standard hours.

The Freshbox project is the exemplification of using the logic of intermediate solutions. In order to reduce high costs of reaching a retail client, as well as to increase comfort, Frisco.pl decided to buy 3 Freshbox machines.

Freshbox is a huge fridge divided into sections. The person willing to use it, enters Frisco.pl website, chooses wanted food products and points out a given Freshbox as a pick-up point. The Frisco.pl worker delivers shopping for several clients and puts it into separate sections after collecting orders. The emphasis on several people being attended simultaneously is not accidental. It all adds up to reduce delivery costs through spread it on several people. In order not to make potential clients wait long and feel uncomfortable, Freshbox is placed in the areas of great number of users and, simultaneously, the access to it is not free for strangers (the lack of vandalism risk). Office buildings are Freshbox ultimate destination. Potential clients, going to work (various hours) pick up the package from the Freshbox. It means convenience referring to place and time, as they do not have to circle around going home in order to do the shopping and the picking time is up to client.

Freshbox is innovative itself due to the fact that it is a fridge at the same time. Cooling functions are indispensable in distributing food products. The author himself knows, at least, one case of using package boxes to distribute food products. However, the intermediate solution introduced by Seiyu company in Tokyo agglomeration did not have the cooling function (Ogawara 2003, p. 727).

Exposing Freshboxes in the 'white collars' working place is another innovative feature. It is connected with the assumption that higher rank workers work long hours and once they finish their work, they dream about being at home fast. Other words, they will be willing to pay for receiving food products immediately.

\section{Research design}

The Freshbox project is a new solution in technical and market sense. Therefore, the author has set himself two goals. The main objective is the analysis of innovative solutions to the last mile issue. The second objective is to evaluate the usefulness of Freshbox project made by three groups of potential customers. 
The paper employs a qualitative research design. Qualitative approach in research is relevant to the study of social change, particularly changes in the organization (Konecki 2000, p. 24). Qualitative research is characterized for the following advantages (Konecki 2000, p. 126; Naslund 2002, p. 321):

- low standardization of research instruments, which allows for increased knowledge about the phenomenon, beyond the researcher's assumptions (explore context),

- matter-of-fact nature of this type of research, manifesting itself in looking at the research problem from the perspective of the decision maker (action context),

- an unlimited expression of the respondents - which is deep and many-faceted exposure of the subject of research (detailed context).

Semi-structured interviews were designed to provide research questions, including:

RQ1. What is the attitude of Polish Internet users toward automatic solutions for tackling the problem of last mile?

RQ2. What are chances of the market success for the Freshbox project?

Study oriented on getting to know opinions about Freshbox project among three groups of potential clients:

1. GROUP A - regular 'day' management students. Their career path (managers all levels) and their belonging to $Y$ generation (22 year olds on average) knowing ICT well is the assumption for choosing this group.

2. GROUP B - managing or finances extramural students. Combining professional experience 'white collar workers' with their openness to new knowledge. People over 30 were predominant in this group.

3. GROUP C - workers of one of the bank branch in Wroclaw, working in an office building. The identity of the analyzed group with the Freshbox target group was the assumption.

The number of respondents was limited by their willingness to share opinions about the new, unknown to them, subject. Finally one collected 85 fully filled questionnaires (27 out of them concerned the group A, 36 - Group B, and 22 Group C). The research was conducted in the 3rd and 4th quarter of 2010.

\section{Evaluation the market potential of the project Freshbox in the opinion of potential customers}

The Freshbox project is a new solution on the Polish market. Therefore, the author decided to determine interest of potential clients asking them some questions. 
Previous experience with on-line shopping was posed to office workers (B and C groups) as the first question of the conducted research. The particular interest was shifted to determine whether, or not, respondents were buying food products via the Internet. One can assume that such people would appreciate the possibility of using Freshbox service more. Table 2 shows the research results.

Table 2. Previous respondents experience with on-line shopping - as a percentage of respondents in each group

\begin{tabular}{l|c|c|c|c}
\hline \multirow{2}{*}{ Group } & \multicolumn{2}{|c|}{$\begin{array}{c}\text { Experience with online shopping (all } \\
\text { categories of products) }\end{array}$} & \multicolumn{2}{|c}{$\begin{array}{c}\text { Experience with online grocery } \\
\text { retailing }\end{array}$} \\
\cline { 2 - 5 } & Yes & No & Yes & No \\
\hline Group B & $97 \%$ & $3 \%$ & $22 \%$ & $78 \%$ \\
\hline Group C & $73 \%$ & $27 \%$ & $18 \%$ & $82 \%$ \\
\hline \multicolumn{5}{c}{ Source: own study }
\end{tabular}

In case of both groups under analysis (B and C groups) one can talk about the spread pattern of using the Internet for transaction purposes. Almost $3 / 4$ of people in group $\mathrm{C}$ and almost the whole population of group $\mathrm{B}$ were buying products from various assortment categories. A typical respondent happen to buy different things via the Internet, but not food products.

Food is the product being bought via the Internet by every fifth respondent. It is a very high result in comparison to the national percent of people searching for food products via the Internet. One has to remember, however, that sampling was of intention-based character and was focused on people familiar not only with the informative but also with transaction aspect of the Internet. The interest in buying food products via the Internet can be beneficial for the Freshbox project, taking market chances into account.

The estimation of market chances of the Freshbox service was the first subjectrelated issue in research. Respondents did not have any chance to encounter such service personally. They were estimating Freshbox chances for success basing on their own purchase, professional, cuisine experience. Table 3 comprises typical opinions related to the project's future, ordered according to the respondent's attitude to market chances of the project.

Results are not equivocal. The majority of respondents is rather positive as for the market chances on the one hand (see the answers: big and small chances). Exemplary respondents' opinions: 'A company tries to fits in the needs of highly 
educated clients who are aware consumer'. 'Workers of the corporation have little time for shopping (there are conditions for Freshbox in big cities where time needed for commuting to work and coming back is long'. 'Business consumer do not have time to wait for the order at home'. 'It is an ideal solution for people who spend most of the day at work'. 'I work in the office myself and I know that such a solution will be successful due to convenience of everyday shopping'.

Table 3. The chances of market success of the project "Freshboxes" in the opinion of the respondents - as a percentage of respondents in each group

\begin{tabular}{l|c|c|c}
\hline & Group A & Group B & Group C \\
\hline Big market chances & $40,7 \%$ & $58,3 \%$ & $27,2 \%$ \\
\hline Small chances for success & $37,0 \%$ & $36,1 \%$ & $27,2 \%$ \\
\hline The lack of any market chances & $22,3 \%$ & $5,6 \%$ & $45,6 \%$ \\
\hline
\end{tabular}

Source: own research

Respondents appreciated the possibility of reducing time loss and greater convenience for the target group - overworked professionals in general. The lack of necessity of doing the shopping after work, the possibility of ordering food via the Internet at any time, of avoiding queues, limiting the distance of carrying bought products (Freshbox - own car) are mainly noticed advantages of the Freshbox service. Respondents highlighted specific conditions after which the service may be beneficial for Frisco.pl: frequent deliveries respectively (logistic aspect), suitable assortment (market aspect), machine localization (organizational aspect), order in accordance with description (trust).

However, there is a distance referring to chances for success of the Freshbox project - especially noticed in group C. The bank workers were most skeptical towards the offered solution. $45,6 \%$ of the bank workers stated that they do not see market chances for the Freshbox project. 22,3\% of regular 'day' students and $5.6 \%$ of extramural students were of similar opinion. The necessity of change of the basic purchase habits in reference to food products, as well as trust towards high quality of products delivered to the Freshbox is the main failure. Exemplary negative responses estimating market chances observed during the survey: 'It may be successful among foreigners and people not knowing the city'. 'One needs a lot of time to be really inclined to it - it is a too much innovative solution'. 'The Polish society is not ready for such changes'. 'This project will reach too narrow circle of clients'. 
Opinions of people who were buying food products via the Internet earlier are particularly interesting. Table 4 shows their opinions about success or defeat of the Freshbox project.

Table 4. Market chances of the Freshbox Project estimated by the respondents buying food products via the Internet earlier - as a percentage of respondents in each group

\begin{tabular}{l|c|c}
\hline The future of the project & Group B & Group C \\
\hline Success & $62, \%$ & $50 \%$ \\
\hline Defeat & $37,5 \%$ & $50 \%$ \\
\hline
\end{tabular}

Source: own research

Opinions were divided equally among the bank workers (Group C). It is worth to note, however, that the bank workers highlighted the necessity of functioning and estimating the project in a longer time perspective - there must be some period for clients to get accustomed to the new solution. There were slightly better opinions related to the positive future of the Freshbox project among extramural students (group B). However, it is not a definite predominance, as it could be observed among all the group B respondents $(94,4 \%)$.

Chances for market success are strictly connected with the target group. Respondents opinions regarding this issue shows table 5.

Table 5. Expectations of the target group in accordance with the way of delivering food products in the framework of the Freshbox project - as a percentage of respondents in each group

\begin{tabular}{l|c|c|c}
\hline & Group A & Group B & Group C \\
\hline Accordance & $66,6 \%$ & $75,0 \%$ & $27,2 \%$ \\
\hline $\begin{array}{l}\text { Accordance under } \\
\text { condition }\end{array}$ & $22,2 \%$ & $16,7 \%$ & $45,6 \%$ \\
\hline The lack of accordance & $11,2 \%$ & $8,3 \%$ & $27,2 \%$ \\
\hline \multicolumn{2}{|l}{}
\end{tabular}

Data in table 5 generally prove accordance of the Freshbox service to the needs of the target group. Group $\mathrm{C}$ being an exception in this regard, is quite skeptical again as for the above accordance. Opinions highlighting adjustment of the 
project were based predominantly on the lack of time of this group and the will to avoid unwanted visit in a traditional shop. The following statements appeared in this context: 'I think that the target group will like the form of such a purchase I order when I want, I pick it up after work and I go home with the shopping'. 'The food can be taken at our convenience, one does not have to wait for the courier'. 'The food is in the fridge, so freshness is guaranteed'. 'No necessity to wait for the courier at home - it helps to plan our day in a flexible way. 'Consumers having no time during the whole week for shopping have to devote Sunday for these activities. In case of Freshbox, Sunday will be truly a day off'.

Respondents pointed out assumptions showing the lack of adjustment of the Freshbox service to the expectations of overworked professionals. The following statements can be found on this list: 'The group of white-collar workers do not eat meals at home'. 'They should not carry bags to their penthouses, even though they do have elevators'. 'Usually they have long distances to their house in the suburbs Waiting in traffic jams does not contribute to maintain freshness'. 'Such people have to touch and see - it will not work'. 'Too big risk of receiving unattractive products'.

Generally speaking, the lack of adjustment of the Freshbox service to the target group is the derivative of high expectations of this group towards products, this group's image and their own inquisitiveness. Some opinions sound as if they were of anecdotic nature, nevertheless they signal a problem noticed by respondents. Respondents form $B$ and $C$ groups identifying themselves with the target group show certain anxiety related to buying via the Freshbox. It is reflected in 'yes, but' and 'yes, but under certain conditions' statements. The most frequently noted reservations: 'Buying food products is reserved for women in Poland. The majority of people employed in corporations are men. "....) It will be interesting for singles'. 'They can have certain reservations to the size of Freshboxes and its localization'. 'If the given product was ordered the previous day in the evening and one could pick it up after work, it would be a tempting solution. 'I am afraid of limited assortment'. 'Food products have to be really of high quality - not only in declarative sphere. The best for it was slow food'.

Formulated reservations are de facto boundary conditions of interest in this form of delivery by a group of busy professionals. Frisco.pl offer will have to meet high quality realistic criteria (to be fresh, on time and should not exceed two days among the order and delivery) for them to be an attractive one. A wide range of assortment is a very important issue - the order has to be complete. Having met all the above criteria, the expectations of the target group will be met. 


\section{Conlusion}

The Freshbox Project is undoubtedly an innovative solution of the last mile issue in the context of online groceries. Aggregating demand of the greater number of clients allows Frisco.pl limiting logistic costs at keeping the remaining benefits out of ordering food products via the Internet, and maintaining convenience and time saving for the client simultaneously.

Conducted research indicate a generally positive reception of the Freshbox service. However, it is not delight deprived of criticism. Many respondents enumerate conditions that have to be met for the market success of the discussed innovation in the long run. This context forces to mention quality and freshness of food products, fast delivery and wide assortment, as well as Freshbox localization and service criteria.

The above criteria do not form a complete list assuring market success for the Freshbox project in the opinion of the author of this article. The number of potential clients and inclination to buy using Freshbox are the basic issues referring to the target group.

Ordering food products via the Internet with door-to-door delivery is still a huge revolution for typically observed purchase habits in Poles. The number of Internauts buying food products via the Internet proves it $(60000)$. It is not much in comparison to the total number of the Internet users in Poland (15 million). According to the Rogers' diffusion curve, there are two most open groups (innovators and early adopters) taking the advantage of buying food products via the Internet. One can even say that the majority of those who buy food products online belongs to the first group. Adding to this relatively small group of clients another possibility of picking up food products ordered online, Frisco.pl is one step further in comparison to the contemporary times. It strengthened its leader position in online grocery segment from the image and competitive point of view on the one hand but there remains a question concerning the financial aspect of the discussed project on the other hand. One should assume that Freshbox is a deficiency undertaking. The machine placed in Agora office building will be a profitability test of such a type of service, analyzed not only by Frisco.pl but also by the competitors.

The research faces conclusive limitations due to a small number of respondents. Further research could reflect opinions of real clients - users of the Freshbox service and should be of the quantitative character to a greater extent. 


\section{Summary}

Keywords: innovation, e-business, the last mile problem

Innovations in e-business - new ways of delivery of food products over the Internet in the opinion of potential customers According to research online sales of food enjoy bigger and bigger Internet users interest. However, selling online such products isn't free from logistic costs connected with the necessity of the geographically-spread client on the one hand and an indispensably fast delivery of food on the other hand.

This article aims at presenting an innovative Freshbox project that may solve the last mile issue in online grocery. The Freshbox project is about installing a vending machine - refrigerator in an office building giving out previously ordered food products via the Internet. The author presented an analysis of online grocery, characteristics of the Freshbox project, as well as results of research conducted among potential clients referring to the following points: market chances for Freshbox project and the conditions of success in the eyes of potential customers.

Streszczenie

Innowacje w e-biznesie - nowe sposoby dostarczania produktów spożywczych zakupionych poprzez Internet w opinii potencjalnych klientów

Dostępne badania wskazują na rosnące zainteresowanie zakupami produktów spożywczych w Internecie. Jednakże specyfika produktów spożywczych generuje koszty logistyczne wiążące się z koniecznością obsługi rozproszonego geograficznie klienta indywidualnego w maksymalnie szybklim czasie.

Celem artykułu jest zaprezentowanie innowacyjnego projektu, który mógłby przyczynić się do rozwiązania problemu ostatniej mili. Freshbox jest urządzeniem, które pełni rolę automatu sprzedającego, a przy tym posiada funkcje chłodzącą. Umożliwia odbiór w miejscu publicznym wcześniej zamówionych przez Internet produktów spożywczych. W artykule przeanalizowano wady i zalety kupowania produktów spozywczych w Interencie, jak również wyniki badań dotyczące rynkowych szans oraz

Słowa przesłanek sukcesu projektu Freshbox.

kluczowe: innowacje, e-biznes, problem ostatniej mili 


\section{References}

1. Anonym (2010), Juz 10 procent brytyjskiego handlu w Internecie, ttp:// biznes.gazetaprawna.pl/artykuly/394628,juz_10_procent_brytyjskiego_ handlu_w_internecie.html.

2. Edmondson A.M., McManus S.E., (2007), Methodological fit in management field research, "Academy of Management Review", Vol. 32, No. 4.

3. Esser K. (2008), Last mile logistics. E-commerce and its impact on transport in urban areas and innovative approaches in city logistics for solving the last mile issue, http://www.bestufs.net/download/BESTUFS_II/national_ seminar/Abgesagter_Termin/BESTUFS_Presentation_Berlin.pdf.

4. Grzechowiak M. et al. (2010), Internet 2k10, http://files.idg.pl/news/ Raport_Internet_2k10.zip.

5. Huang Y., Oppewal H. (2006), Why consumers hesitate to shop online: An experimental choice analysis of grocery shopping and the role of delivery fees, "International Journal of Retail \& Distribution Management", Vol. 34, No. $4 / 5$.

6. Konecki K. (2000), Studia z metodologii badan jakosciowych, PWN Publishing House, Warsaw.

7. Laskowska H. (2009), Lepiej kupowac zywnosc w nternecie, http://e-biznes. $\mathrm{pl} / 2009 / 02 /$ lepiej-kupowac-zywnosc-w-internecie/.

8. Milkman K.L., Rogers T., Bazerman M.H. (2010), I'll have the ice cream soon and the vegetables later: A study of online grocery purchases and order lead time, "Marketing Letters", Vol. 21, No. 1.

9. Naslund D. (2002), Logistics needs qualitative research - especially action research, "International Journal of Physical Distribution \& Logistics Management", Vol. 32, No. 5.

10. Ogawara S. et al. (2003), Internet grocery business in Japan: current business models and future trends, "Industrial Management \& Data Systems", Vol. 103 Iss. 9.

11. Ramus K., Nielsen N.A. (2005), Online grocery retailing: what do consumers think?, "Internet Research", Vol. 15, Iss. 3.

12. Robinson $\mathrm{H}$. et al. (2007), The role of situational variables in online grocery shopping in the UK, "The Marketing Review", Vol. 7, Nr 1.

13. Weltevreden J.W.J (2008), B2C e-commerce logistics: the rise of collectionand-delivery points in The Netherlands, "International Journal of Retail \& Distribution Management", vol. 36, No. 8. 